\title{
“Artillery Properly Distributed": Ten or Twelve Guns with the Continental Advance Corps at Monmouth Courthouse
}

\section{By Michael Timpanaro and Victor Pidermann}

\section{DOI: http://dx.doi.org/10.14713/njs.v5i1.151}

In writing this article, the authors sought to answer how many artillery pieces were actually present with General Charles Lee's advance corps at the Battle of Monmouth. The various existing sources disagree on the number, ranging from ten to twelve guns. Based on re-analysis of primary and secondary sources, this paper surmised that there were in fact five separate artillery companies, with two guns each, attached to the advance corps, for a total number of armament fixed at ten guns.

This conclusion was reached through a several-step process, begun initially by conducting an in-depth historiography of the primary and secondary sources that discussed these artillery numbers at the Battle of Monmouth. After this review, the structure of the Continental Artillery, as it was incorporated into Washington's Army, was analyzed. With the insights gained from these studies, the final step sought to reconcile these two sets of data to resolve the question at hand. Next, based on the conclusions reached, this article proffers the identities of the artillery companies of the advance corps. The further evidence collected from artillery unit muster rolls and other primary sources clearly identified four of these companies while providing strong circumstantial evidence in naming the fifth and final artillery unit.

\section{Introduction}

This is the first paper in what the authors hope will be a series on the role of the artillery at the Battle of Monmouth Courthouse, near the present-day Borough of Freehold, NJ. One of the most notable facets of this engagement is the usage of artillery - the Battle of Monmouth is known for having the largest field artillery duel of the American Revolution. Despite this, little has been 
written to date about the artillery at the Battle. In fact, most of the histories and research on the Battle of Monmouth have concentrated on the movements of generals and the infantry, the footunits of the army.

The impetus for this series came about from one specific visitor inquiry at Monmouth Battlefield State Park. A common enough question was asked of Park staff-members: "I think one of my ancestors was here at the battle...can you give me any information...?" This is a fairly typical question, except when it came to this particular ancestor, who was a Continental artillerist. What initially started as a relatively simple research task has led to an intensive reevaluation of the entire battle from a distinct perspective.

To best carry out this reevaluation of the Monmouth campaign's usage of artillery, the series will divide the battle into different phases and topics in order to follow and identify as many of the artillery units as possible. This research will attempt to answer a number of questions and clear up some confusion from earlier accounts of the battle. This first paper will concentrate on the morning phase of the Battle of Monmouth, with the objective of identifying each of the artillery companies present in the initial attack of Major General Charles Lee and his advance corps on the rearguard of the British forces on that hot and humid day of June 28, 1778.

The morning phase of the Battle of Monmouth contains a significant amount of what is known about the Continental artillery during the campaign. It also presents one of the more confusing elements pertaining to the artillery - how many artillery pieces were actually present with General Lee's advance corps in the fighting of the morning? Various sources disagree; some state that there were ten guns with this advance force, some claim that there were twelve, while others play it safe by not making a firm determination, giving a range of "ten to twelve." This uncertainty has led to continued confusion as scholars, interpreters, and the public delve into the 
history of the battle. It is this key dilemma that this paper aims to resolve. Based on re-analysis of primary sources, and by taking a critical lens to secondary sources, this paper surmises that there were in fact five separate artillery companies, with two guns each, attached with Lee's advance corps, with a total number of armament fixed at ten guns.

The best way to reevaluate this issue is to start by doing an in-depth historiography of sources, looking at the history of how the Battle of Monmouth's artillery has been described and depicted over time. After this review, it is important to understand the structure of the Continental artillery as it was incorporated into Washington's army. With the insights gained from these studies, the final step is to reconcile these two sets of data to resolve the question at hand.

\section{Historiography}

One of the earliest sources describing the make-up of the Continental advance corps' artillery is a memorandum penned by Brigadier Generals Anthony Wayne and Charles Scott to George Washington on June 30, 1778, a mere two days after the fighting at Monmouth Courthouse. To provide some context to this piece, both Wayne and Scott commanded separate infantry detachments of brigade strength in the morning portion of the Battle. This document was most likely sent to the Commander-in-Chief as a precautionary measure by the brigadiers. Both subordinate commanders anticipated that their immediate superior during the morning fight, Major General Charles Lee, was likely to face an inquiry in the near future. This memorandum amounted to an early deflection of blame on their part, a fact that would set the stage for the trial to come. The document begins by stating the composition of forces in Lee's advance corps, and, most importantly, the number of guns with that force: "We received orders to march with the...detachments... with ten pieces of artillery properly distributed among the whole." ${ }^{1}$ This is the

\footnotetext{
${ }^{1}$ William S. Stryker, The Battle of Monmouth, ed. William Starr Myers, 1927 (Reprint, Tennent, NJ: Friends of Monmouth Battlefield, 1999), 284.
} 
earliest primary source detailing an exact number of guns, clearly stating that count being set at ten.

Less than a week later, on July $4^{\text {th }}$ in New Brunswick, NJ, the court-martial of Charles Lee began. The series of testimonies that came out of those proceedings are still considered to this day to be among the earliest and, in many cases, the most thorough primary source evidence for the morning and mid-day segments of the Battle of Monmouth. The "Court-Martial" serves both as the source for most of what we know about the advance corps' artillery as well as the confusion surrounding the number of artillery pieces brought to bear on the British that morning. The confusion began, ironically enough, with the testimony of General Wayne. In what seems like a departure from his earlier memorandum of June $30^{\text {th }}$, Wayne gives an accurate description of the forces amassed under General Lee's command at the battle, however, the number of artillery pieces jumps mysteriously from ten to twelve. Wayne was asked: "What number of troops marched under the command of General Lee towards the enemy the $28^{\text {th }}$ of June?" to which the brigadier responded:

In front, Colonel Butler, with two hundred, Colonel Jackson, with an equal number, Scott's own brigade, with a part of Woodford's, six hundred, with two pieces of artillery, General Varnum's appeared about the same number, with two pieces of artillery, my own detachment was about one thousand, and two pieces of artillery, General Scott's detachment, fourteen hundred, and four pieces of artillery, General Maxwell's was one thousand, and two pieces of artillery; in all, five thousand, with twelve pieces of artillery, exclusive of the militia. ${ }^{2}$

General Scott's testimony neither clarified nor increased the confusion presented by Wayne's statements. Unlike his joint participation with Wayne in the memorandum of June $30^{\text {th }}$, Scott gave

\footnotetext{
2 "Proceedings of a General Court-Martial, Held at Brunswick, in the State of New Jersey, by Order of His Excellency General Washington, Commander in Chief of the Army of the United States, for the Trial of Major General Lee, July $4^{\text {th }}, 1778$, Major General Lord Stirling, President," in Collections of the New-York Historical Society for the Year 1873, Publication Fund Series, The Lee Papers, vol. 3, 1778-1782 (New York: New-York Historical Society, 1874): 22.
} 
no definite number of guns, whether for the overall artillery of Lee's advance corps or for the artillery units assigned directly to his detachment. ${ }^{3}$

In addition to these new entries by Wayne and Scott, the "Court-Martial" also introduces the narrative of events from the point of view of the senior artillerist in General Lee's forward element, Lieutenant Colonel Eleazer Oswald. His testimony gives the over-all number of the artillery in the morning to ten guns. Oswald goes on to state that at one point in the fighting of the morning he formed a "grand battery" of the artillery companies of the advance corps, detaching these units from their assigned infantry brigades to form one single body of massed artillery. ${ }^{4}$

Oswald, in his testimony, clearly defined the different units with which he built up his "grand battery." For most of the morning, he had personally supervised the two-gun company of Captain Thomas Wells [assigned to Colonel Grayson's Detachment (Scott's Brigade)]. As Lee's forces pulled away from the vicinity of the town, Oswald gathered the two-gun company assigned to General Varnum's Brigade and a two-gun company assigned to General Wayne's Detachment. Later during the retreat, Oswald also obtained the two-gun company attached to General Scott's Detachment and the two-gun company attached to General Maxwell's New Jersey Brigade. The units gathered throughout the course of the morning, beginning with the initial skirmish of the day through the retreat, brought the total number of guns in Oswald's battery to ten. ${ }^{5}$

The above two references from the "Court-Martial," the ten guns of Oswald's account and the twelve of Wayne's testimony, along with the Wayne-Scott "Memorandum," affected secondary sources writing on the Battle of Monmouth for generations. One example of this influence was seen in the oration given by Henry Armitt Brown at the centennial anniversary of

\footnotetext{
3 “Court-Martial," 27-29.

${ }^{4}$ Ibid., 133.

${ }^{5}$ Ibid., 133-135.
} 
the battle in 1878. In his re-telling of the morning events of the battle, Brown states that General Lee had twelve pieces of artillery distributed throughout the forces under his command. ${ }^{6}$

Brown's 1878 commemorative "Battle of Monmouth Oration" was published years later, in 1913, and is a classic example of Victorian portrayals of history, a style which used elements from primary sources, in this case, the Lee "Court-Martial," along with local traditions (often hearsay) in its retelling of history. Additionally, the 1913 appearance of Brown's oration in a published format, a volume in the "Classics in the Grades Series," is an example of works known as "school histories," meant to educate school children of the nineteenth and early twentieth centuries. These school histories, endeavoring to teach varied subjects related to world and American history, used orations on these topics to help sharpen the oratorical skills of these students. Brown's oration and similar legend-histories were common sources which made up many of the various school histories of the day.

The next major step in trying to describe and interpret the battle developed around the same time as Brown's oration. In 1876, Colonel Henry B. Carrington, a veteran of both the Civil War and Red Cloud's War, published Battles of the American Revolution 1775-1781, which was later supplemented by his Battle Maps and Charts of the American Revolution in 1881. Carrington brought a new approach to the understanding of military engagements; he was an early proponent of military science as a way to learn from past military actions to prepare for current and future battles. These two books by Carrington cover the entire Revolutionary War, with the first giving a detailed description and analyses of its events and battles while the second presents a detailed mapping of battles and other key maneuvers and engagements outlined in his first volume.

\footnotetext{
${ }^{6}$ Henry Armitt Brown, The Battle of Monmouth: An Oration Composed to be Delivered at Freehold, New Jersey, June 28, 1878, the One Hundredth Anniversary of the Battle, Classics in the Grades series, ed. A. J. Demarest (Philadelphia: Christopher Sower Co., 1913), 51.
} 
Carrington's works provide an in-depth description of General Lee's portion of the Battle of Monmouth, including accounts of the artillery. Carrington's works mark the first innovative attempts at combining a military science perspective along with contemporary school histories to support his interpretation of the event. His use of the "Lee Court-Martial" and other period sources, as well as his own research and that of others, along with removing unsubstantiated tall-tales and local accounts, demonstrates his scientific approach in portraying the Battle of Monmouth.

However, in both the 1876 original and the 1974 combined volume reprint, a misstated direct quote from the "Court-Martial" contributes further to the ongoing confusion over the total number of guns in the morning's advance corps. In quoting Wayne's description of the makeup of these units, Carrington lists the units correctly but misquotes the number of artillery pieces that were assigned to Scott's Detachment. As was previously noted, this number was stated as being four guns, however, Carrington's quote of the trial lists this number as two guns. ${ }^{7}$ In researching this issue, all known published versions $(1778,1823,1864$, and 1873) of the "Court-Martial" were verified as stating these guns were set at four, a simple error on Carrington's or his publisher's account which added to the confusion of this issue. ${ }^{8}$

Colonel Carrington's efforts to reduce legendary sources and to conduct a systematic and scientific approach in interpreting the Battle of Monmouth influenced the next prolific historian to

\footnotetext{
${ }^{7}$ Henry B. Carrington, Battles of the American Revolution 1775-1781: Historical Criticism, with Topographical Illustrations (New York: A. S. Barnes \& Co., 1876), 417-418; Henry B. Carrington, Battles of the American Revolution 1775-1781, Including Battle Maps and Charts of the American Revolution, 1877 and 1881 (reprint, Victoria, BC, Canada: Promontory Press, 1974), 417-418.

8 "Court-Martial," 22; Proceedings of a General Court-Martial, Held at Brunswick, in the State of New-Jersey, by Order of His Excellency General Washington, Commander in Chief of the Army of the United States of America, for the Trial of Major General Lee, July $4^{\text {th }}, 1778$, Major General Lord Stirling, President, (Philadelphia: John Dunlap, 1778), 9; Proceedings of a General Court-Martial, Held at Brunswick, in the State of New-Jersey, by Order of His Excellency General Washington, Commander in Chief of the Army of the United States of America, for the Trial of Major General Lee, July 4 ${ }^{\text {th }}$, 1778, Major General Lord Stirling, President, 1778 (reprint, Cooperstown, NY: J. H. Prentiss, 1823), 16; Proceedings of a General Court-Martial, Held at Brunswick, in the State of New-Jersey, by Order of His Excellency General Washington, Commander in Chief of the Army of the United States of America, for the Trial of Major General Lee, July 4th, 1778, Major General Lord Stirling, President, 1778 (reprint, New York: J. M. Bradstreet \& Son, 1864), 27.
} 
weigh in on the subject. Shortly before his death in 1900, William S. Stryker completed his work on the battle entitled The Battle of Monmouth. Stryker was a veteran officer of the Civil War, the longest-serving Adjutant General of New Jersey in the state's history, a renowned scholar of New Jersey military history, and long-time president of the New Jersey Historical Society. A contemporary of Carrington's, Stryker was cited by Carrington in his 1876 Battles of the American Revolution as being an invaluable resource on the Revolutionary War battles in New Jersey. ${ }^{9}$ Most well-known for his The Battles of Trenton and Princeton, Stryker passed away before he found a publisher to print his final work on the Battle of Monmouth, and the work remained in his widow's possession for nearly three decades.

In 1927, Helen Boudinot Stryker, the author's widow, placed the manuscript for The Battle of Monmouth in the hands of Princeton University political historian William Starr Myers. Mrs. Stryker gave full editorial rights to Myers, who prepared Stryker's work for publication through Princeton University Press. The one caveat that Stryker's widow placed on this transfer was in ensuring that Myers gave full credit to Stryker's “extensive research and painstaking work" in preparing the piece. ${ }^{10}$ Regarding his editorial influence on Stryker's work, Myers mentions in his "Introductory Note" that:

Other conditions of publication have made necessary the partial abridgement of the narrative and also the omission of some hundreds of pages of documents...I have made the endeavor to include everything of especial value and also, in making minor corrections, to preserve the original form and style of presentation as far as possible. $^{11}$

An extensive effort to locate these omitted documents at various repositories has been unsuccessful. Despite Myers' heavy editorial work on the piece, Stryker's The Battle of Monmouth

\footnotetext{
${ }^{9}$ Carrington, Battles of the American Revolution, Historical Criticism, 659.

${ }^{10}$ Stryker, Battle of Monmouth, "Introductory Note."

11 Ibid.
} 
is still considered to be one of the single most influential and most complete secondary sources detailing the Battle of Monmouth to date.

Most of the current interpretation on the battle, including accounts of the Continental artillery, either comes directly from or is heavily influenced by Stryker's The Battle of Monmouth. In his account, Stryker perpetuates the question of the correct number of guns by first mentioning twelve artillery pieces in his initial description of the makeup of the morning Continental forces under General Lee. ${ }^{12}$ The author later details the composition of Lieutenant Colonel Oswald's "grand-battery" during the advance corps' retreat from the vicinity of Monmouth Courthouse back towards the main Continental lines. Stryker here states that Oswald had ten guns in his grand battery, listing one two-gun company as having been assigned directly under him and identifying four other two-gun companies by name. ${ }^{13}$ Despite several issues that will be discussed at a later point in this analysis, the twelve-guns or ten-guns conundrum is given further weight by the lack of clarity in Stryker's work (at least as it was presented under the editorship of William Starr Myers.) To further compound the issue, Stryker's The Battle of Monmouth includes additional primary sources in its appendices, of note the Wayne-Scott "Memorandum" suggestive of ten-guns, that vexes the subject further. ${ }^{14}$

The next major step in the interpretation of the battle came with the renewed interest in the American Revolution in general during the period leading up to and including the Bicentennial. The stand-out account, The Battle of Monmouth, by Samuel Stelle Smith, was written as part of a series of short volumes in the "Bicentennial Series on the American Revolution," published by the

\footnotetext{
${ }^{12}$ Stryker, Battle of Monmouth, 116.

${ }^{13}$ Ibid., 193.

${ }^{14}$ Ibid., 284.
} 
Philip Freneau Press during the 1960s and 1970s. In the preface of Smith's volume, Dr. Peter J. Gunthorn states, "for the first time the Battle of Monmouth is made understandable."15

Smith's volume appears to revert back to the earlier era of combining historical facts with local stories and accounts. In several instances he uses the traditional stories to fill in the gaps of the primary sources he references. He does, however, mention the artillery as it helps to move the events of his short history of the battle forward. Smith breaks down the forces of the morning, attaching artillery companies with infantry brigades, detailing their role in the morning's engagement. In Smith's initial discussion of the advance forces he lists the distribution of the artillery companies thusly:

Col. Grayson did not get under way from Englishtown until about six A.M. Included in his detachment were four pieces of artillery, under the command of Lieutenant Colonel Eleazer Oswald of the $2^{\text {nd }}$ Artillery regiment...Maj. Gen. Lee's main force broke camp and started about seven A.M.,...The order of march was: Brig. Gen. Wayne's and Brig. Gen. Scott's detachments under the command of Maj. Gen. la Fayette, followed by Brig. Gen. Maxwell's brigade. Col. Jackson's small detachment formed the rear. There were eight pieces of artillery with Lee's main force, two assigned to Wayne, four to Scott and two to Maxwell. ${ }^{16}$

Smith's above listing of the line of march, including the distribution of the artillery, is not the clearest presentation of this information, and may in fact contribute to the confusion. This same information is more concisely presented later in his work in chart form. ${ }^{17}$ More importantly for the purposes of this current discussion, in both places Smith identifies the total number of artillery pieces as twelve.

Smith's lack of clarity did indeed affect the next set of historians who discussed the Continental artillery at Monmouth. In 1993, David G. Martin authored The Philadelphia Campaign, June 1777 - July 1778, a volume of the "Great Campaign Series." While the focus of

\footnotetext{
${ }^{15}$ Samuel Stelle Smith, The Battle of Monmouth, (Monmouth Beach, NJ: Philip Freneau Press, 1964), 3.

${ }^{16}$ Smith, Battle of Monmouth, 9.

${ }^{17}$ Ibid., 28.
} 
the work centers on British and Continental efforts in and around Philadelphia from 1777 to 1778, the last sections of the piece deal with the British withdrawal from that city and, specifically, the events surrounding the Battle of Monmouth. More importantly for this historiography on the Continental artillery of the morning engagements of the battle, Martin names the units of Lee's advance corps along with the exact number of artillery pieces assigned to each element. Martin adopts the mainstream view that Lee's forces had twelve guns. In his work, Martin uses Smith's system for naming and organizing Lee's various elements, a choice that perpetuates the confusion. $^{18}$

The twenty-first century has brought with it a new interest in trying to understand and interpret the Battle of Monmouth. Brendan Morrissey, a British author of military history, is one of the new authors to attempt to reinterpret this complex battle. In his Monmouth Courthouse 1778, volume 135 of Osprey's "Campaign Series," Morrissey uses a combination of primary and secondary sources to compile his summary of the battle and illustrates his account with the use of a series of maps of key phases of the engagement. Morrissey's use of multiple maps in his book to help interpret different aspects of the Battle was a major step forward in published accounts to try to deal with this complicated battle.

As with many of his predecessors, Morrissey only addresses the artillery in a cursory fashion. It is mentioned in passing as it relates to other discussed elements, though he does use accounts of Oswald and various numbers of artillery pieces, including Oswald with a ten-gun "grand battery." 19 As to how many pieces of artillery were with Lee in the morning, Morrissey

\footnotetext{
${ }^{18}$ David G. Martin, The Philadelphia Campaign, June 1777 - July 1778, Great Campaigns Series (Conshohocken, PA: Combined Books, 1993), 210-211.

${ }^{19}$ Brendan Morrissey, Monmouth Courthouse 1778: The Last Great Battle in the North, Campaign Series no. 135 , ed. Lee Johnson, (Oxford, UK: Osprey Publishing, 2004), 42.
} 
depicts twelve Continental artillery pieces in the field on his map, "Monmouth Courthouse - Lee's Advance."20

One of the more interesting references to artillery pieces comes from his discussion of Lee's retreat, in which he states that "Maxwell took the two heaviest of Scott's six guns."21 Though Morrissey does continue using the twelve-gun interpretation, his statement about Scott and Maxwell exacerbates the confusion of the issue of the number of guns. However, when he gives the order of battle for Lee's advanced corps, he lists twelve guns, identifying four named companies, of two guns each, and four unidentified guns as coming from the $3^{\text {rd }}$ (Crane's) Artillery Regiment. $^{22}$

In 2010, Joseph G. Bilby and Katherine Bilby Jenkins co-wrote Monmouth Courthouse: The Battle That Made the American Army, the next work in the historiography on the Continental artillery in the morning. For their discussion on these artillery pieces, Bilby and Jenkins relied heavily on secondary sources, primarily Smith (as interpreted by Martin), in their new narrative. Their conclusions as to the total number of field pieces are, in a word, unique:

Grayson's Detachment...was supported by two artillery pieces...Varnum's Brigade was supported by two artillery pieces...Anthony Wayne's 1,000-man detachment with four artillery pieces, and then Scott's men with four more guns..."Scotch Willie" Maxwell...with his Jerseymen, supplemented by two artillery pieces. ${ }^{23}$

Based on the numbers given, Bilby and Jenkins suggest that there were fourteen total artillery pieces with Lee's command in the morning. This number, however, may be attributed to their usage of Martin's (and, ultimately, Smith's) organization for the different morning units, which

\footnotetext{
${ }^{20}$ Morrissey, Monmouth Courthouse 1778, 42-43.

${ }^{21}$ Ibid., 52.

22 Ibid., 85.

23 Joseph G. Bilby and Katherine Bilby Jenkins, Monmouth Courthouse: The Battle That Made the American Army (Yardley, PA: Westholme Publishing, 2010), 186-187.
} 
may have further confused their own interpretation of the amount of artillery pieces present. ${ }^{24}$ To confound the numbers-issue further, at another point the authors return to a different traditional number, mentioning a ten-gun battery formed by Lieutenant Colonel Oswald in the fighting at later portions of the morning. ${ }^{25}$

The most recent and most complete work to date on the Battle of Monmouth is Mark Edward Lender and Garry Wheeler Stone's 2016 Fatal Sunday: George Washington, the Monmouth Campaign, and the Politics of Battle. A decade earlier, in compiling information for his Monmouth Courthouse 1778, Morrissey consulted with Stone and used some of his research for his narrative of the engagement and his maps of the battle. Stone further developed and drew upon this same research when working with Lender in writing Fatal Sunday. ${ }^{26}$

In their book, Lender and Stone compile all the research of the past two centuries, including some new material of their own. In particular, Stone's intimate knowledge of the archaeology of the battlefield and Lender's interpretation of the socio-political situation of the time provides new perspectives on the battle. Concerning the artillery, Lender and Stone adhere to the twelve-gun model. Throughout the body of their work, whenever referencing the number of artillery pieces, they remain consistent to this number. In their initial discussion of Lee's command, they present the traditional twelve-gun distribution throughout the advance corps and maintain these figures into their appendices when presenting their "Continental Army Order of Battle.",27

To summarize the historiography as presented above, certain patterns in relating the events of the Battle of Monmouth have emerged which have affected the interpretation of the issue at

\footnotetext{
${ }^{24}$ Bilby and Jenkins, Monmouth Courthouse, 195; Martin, The Philadelphia Campaign, 210; Smith, The Battle of Monmouth, 28.

${ }^{25}$ Bilby and Jenkins, Monmouth Courthouse, 200.

${ }^{26}$ Morrissey, Monmouth Courthouse 1778, 4.

${ }^{27}$ Mark Edward Lender and Garry Wheeler Stone, Fatal Sunday: George Washington, the Monmouth Campaign, and the Politics of Battle, Campaigns and Commanders Series, vol. 54, Gregory J. W. Urwin ed. (Norman, OK: University of Oklahoma Press, 2016), 190, 451-453.
} 
hand. Brown's 1878 "Battle of Monmouth Oration” exemplifies the popular Victorian method of portraying history in which elements of primary sources were used in conjunction with, and given equal historical weight as, local oral traditions and legend-histories. The primary purpose of these histories was to keep the memory of the events alive and pertinent to that generation. The emphasis of these works was not on the details but rather on the end results. The number of artillery pieces present in the morning in Brown's oration is therefore not given to present strict historical fact but is rather incidental to his re-telling of the events of the battle.

Carrington's and Stryker's work on the battle, however, illustrate a departure from this earlier model, exemplified by Brown's "Oration," in that both authors sought to implement a scientific approach in relating the information and chronology of the battle. Using the primary sources available to them, they sifted through the oral traditions, keeping what they deemed sound while casting out other elements that did not conform to eye-witness accounts. Exact numbers of artillery pieces are presented, based on various primary sources, and are pertinent to their discussion. Due to the methodology and the engaging writing style, these works quickly eclipsed the earlier style of facts-and-legends histories on the battle. For Carrington and Stryker, the details became just as important as the overall portrayal of the battle.

Ironically, the works of the twentieth and twenty-first centuries on the battle have tended, in some cases, to move away from the solely scientific approach advocated by Carrington and Stryker. Many authors of this period have reincorporated some of the local traditional histories and thus have relied more on previous secondary sources than on the original documents. Regarding the Continental artillery, rather than looking at the primary sources afresh, the writers of this period depended heavily on the secondary source authors. In doing so, usage of inconsistent terminologies (i.e., detachments/brigades) and interpretation errors have resulted, in many cases, in each new 
iteration of the history departing ever more so from the facts of the primary sources. This is the crux of the matter: over-reliance of the most recent secondary sources, without a re-examination of the primary sources, has allowed these gun totals to be reported and re-reported for decades without any new and in-depth analysis of the issue. This lack of clarity, confusion, and the reign of error leaves the matter in a stagnant quagmire. It is the role of historians in every generation to reevaluate all forms of prior interpretation, not to simply disregard nor to take at face value what has come before, but to attempt to obtain the definitive truth.

\section{Ten or Twelve?}

In order to obtain this fresh perspective and better determine the true number of guns in the morning phases of the Battle of Monmouth, it is important to grasp the organizational nature of the Continental artillery as devised by Brigadier General Henry Knox. By the Monmouth campaign, Knox's Brigade of Artillery was organized into four regiments, alternatively called battalions. Ideally, each regiment consisted of a command staff of a colonel, a lieutenant colonel, and a major; additionally, there was a support staff consisting of a host of other specialist officers and non-commissioned officers who assisted in the administrative operations of the regiment. ${ }^{28}$

Each artillery regiment was furthered divided into companies, which, depending on the particular regiment, could vary from eight to twelve. Companies were usually assigned two pieces of field artillery, their gun-crews, and their associated ammunition wagons. Each company was commanded by a captain and employed other junior officers to command the gun-crews; these junior officers typically included a captain-lieutenant (a now obsolete rank, between captain and first lieutenant), who served as second in command of the company, and a number of first and second lieutenants. Gun-crews consisted of one field piece and ideally sixteen men, although, due

\footnotetext{
28 Fred Anderson Berg, Encyclopedia of Continental Army Units: Battalions, Regiments and Independent Corps (Harrisburg, PA: Stackpole Books, 1972), 23.
} 
to various factors such as casualties and desertions, the usual number of men working each artillery piece was often far less than ideal. ${ }^{29}$

The company served as the basic tactical unit of artillery for the Continental Army. The British system for artillery, the format most familiar to Continental artillerists at the start of the Revolutionary War, called for each infantry regiment to have a two-gun artillery company assigned to it for each campaign. ${ }^{30}$ In May of 1778 , the Continental Congress adopted a new artillery plan, drawn up by Washington and Knox and loosely based on the British artillery model. Rather than assign artillery to infantry regiments, the Continental model assigned one artillery company to each brigade of infantry (a unit usually grouping three or four regiments or battalions and typically commanded by a brigadier general or a colonel commandant), usually from the brigade's same state, while on campaign. In these instances, the brigade commander would have tactical control over these companies while their parent artillery regiments maintained purely administrative control; they would resume actual command over these sub-units only when reassigned to the Artillery Park, typically during periods of winter encampment. ${ }^{31}$

In Washington's army, each infantry brigade was an element of a larger organizational force, often identified with such various names as divisions, wings, lines, or, as in the case of this discussion, an advance corps. These bodies, made up of three to six brigades, were placed under the command of a major general. Each of these forces were assigned a senior artillerist who was tasked with advising the divisional commander on artillery matters. If the course of battle called

\footnotetext{
${ }^{29}$ William E. Birkhimer, Historical Sketch of the Organization, Administration, Matériel and Tactics of the Artillery, United States Army (Washington, DC: James J. Chapman, 1884), 6; Berg, Encyclopedia of Continental Army Units, 23.

${ }^{30}$ John Muller, A Treatise of Artillery: Containing I. General Constructions of Brass and Iron Guns Used by Sea and Land, to Which is Prefixed, a Theory of Powder Applied to Fire-Arms. For the Use of the Royal Academy of Artillery, 1757 (Reprint: Eighteenth Century Collections Online Print Editions - Medicine, Science and Technology, n.d.), 251.

${ }^{31}$ Berg, Encyclopedia of Continental Army Units, 23; Janice E. McKenney, The Organizational History of Field Artillery 1775 - 2003 (Washington, DC: Center of Military History, United States Army, 2007), 12; Morrissey, Monmouth Courthouse 1778, 25.
} 
for it, the senior artillerist could assume command of the artillery companies assigned to the various brigades of the force and unite them as needed into larger groupings, including into one cohesive unit known as a "grand battery." These formations were used in combat when mass fire was needed as conditions demanded; the senior artillerist could dismiss individual companies back to their assigned brigades once they were no longer required. ${ }^{32}$ It is important to note that these senior artillerists did not command artillery companies of their own; rather, they were field officers (colonels, lieutenant colonels, or majors) from one of the four regiments of artillery.

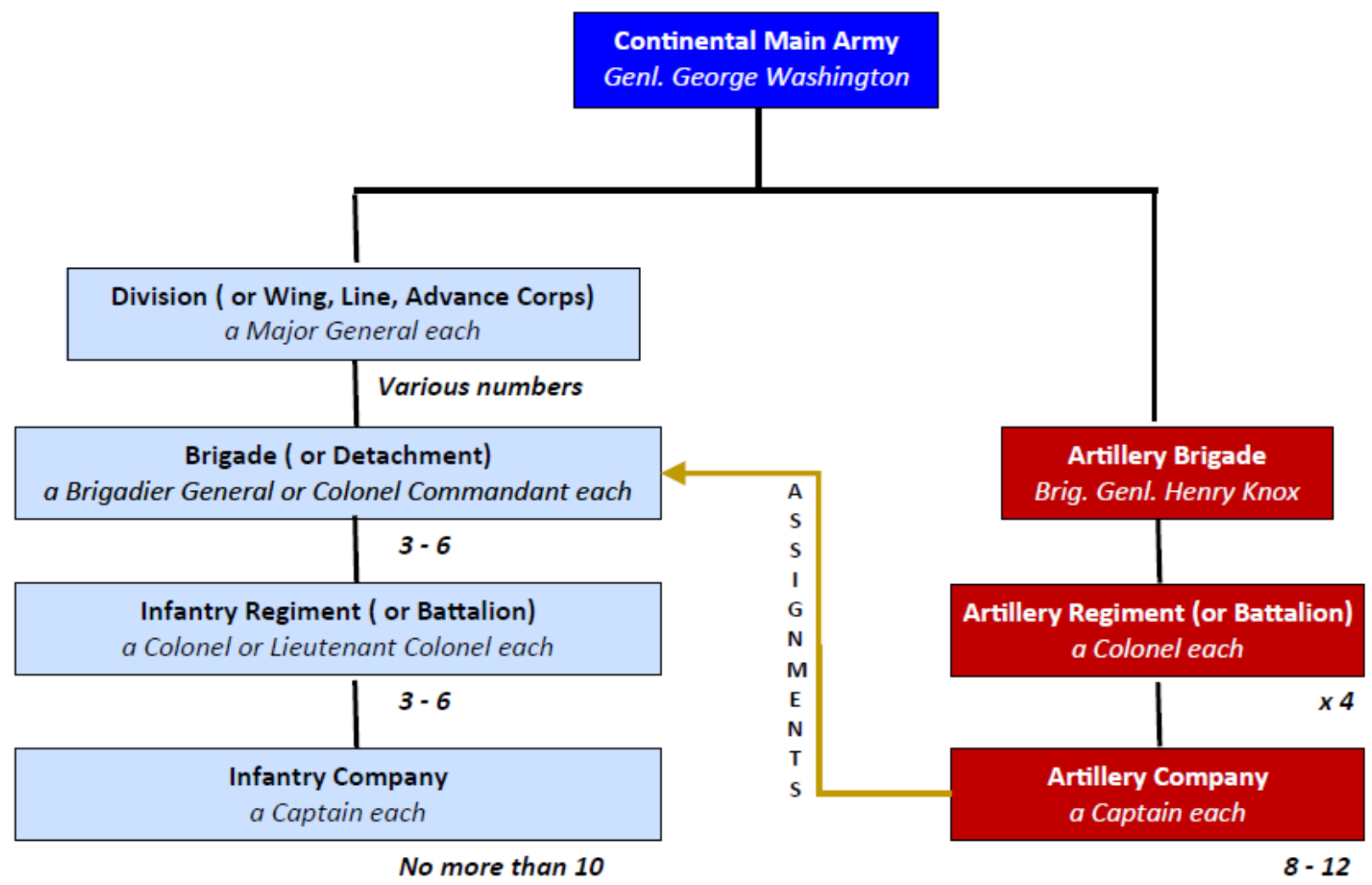

Continental Army Organizational Chart

${ }^{32}$ McKenney, Organizational History of Field Artillery, 13. 
At the Battle of Monmouth, the senior artillery officers assigned to the three divisions actually engaged in combat were all lieutenant colonels: Lieutenant Colonel Edward Carrington, of Colonel Charles Harrison's Artillery Regiment, served in this capacity for the left wing under Major General William Alexander Lord Stirling; Lieutenant Colonel Thomas-Antoine de Mauduit Chevalier Du Plessis, a staff officer at the Artillery Brigade level under General Knox, advised Major General Nathanael Greene with the right wing; and, most importantly for this discussion, Lieutenant Colonel Eleazar Oswald, of Colonel John Lamb's Artillery Regiment, served as the senior artillerist with the advance corps under Major General Charles Lee. ${ }^{33}$ Based on this clear understanding of how General Knox organized and distributed his artillery companies and regimental field officers, now the analysis of "ten or twelve" guns in the morning phase of the battle can commence.

The major focal point of the dilemma truly begins with William S. Stryker and his The Battle of Monmouth, the first major secondary source on the subject, and whose work on the issue at hand serves as the bedrock upon which all other later generations of researchers and historians have built their works. Referring back to Stryker's description of the companies involved with Lee's advance corps and the amassing of Oswald's "grand battery" during the retreat from Freehold, the listing of artillery company commanders cannot be accurate. Stryker writes:

Lieutenant-Colonel Oswald, the brave commander, who had gained so much honor on this field had now his own two-gun battery, Captain Compston's two guns, Captain Cook's two guns, Captain Seward's two guns and Captain Well's two guns.... ${ }^{34}$

\footnotetext{
${ }^{33}$ Charles Konigsberg, "Edward Carrington, 1748-1810: 'Child of the Revolution' - A Study of the Public Man in Young America” (PhD diss., Princeton University, Princeton, NJ, 1966), 32; Lender \& Stone, Fatal Sunday, 451-462; Morrissey, Monmouth Courthouse 1778, 85.

${ }^{34}$ Stryker, Battle of Monmouth, 193.
} 
Lieutenant Colonel Oswald, General Lee's senior artillerist, would not have commanded his own company. Oswald witnessed the morning engagement attached to Captain Wells' Artillery Company, a fact which is clearly attested by Oswald's own words in his testimony in the "Lee Court-Martial. ${ }^{35}$ As such, Stryker's list is incorrect; the Oswald-commanded company and the separate unit commanded by Captain Wells were one and the same artillery company.

The next point that confuses things is the mention of Captains Cook and Compston. While there is indeed a Captain Cook, commander of one of the known artillery companies of the advance corps, there is no Captain Compston. There was a Captain-Lieutenant Cumpston [authors' emphasis] who served as Captain Cook's executive officer for the company and did in fact assume command of the company during the morning phase of the battle when Captain Cook took a devastating wound from enemy musket fire. ${ }^{36}$ Once again, this serves as another case in which Stryker misidentifies artillery company commanders. With Stryker's mistakes and inconsistent gun counts given by Generals Scott and Wayne (as previously mentioned), it is somewhat understandable how so many variations and errors have been allowed to perpetuate in succeeding periods of scholarship on the morning phase artillery.

The crux of the matter, however, deals not with these named companies but with the unnamed artillery unit assigned to General Scott's very own detachment. Countless historians and scholarly works over the years have indicated that there were four guns with Scott's unit, all derived from misunderstanding Stryker's account and the other primary and secondary sources of the historiography. This would indicate that there were possibly two separate companies (each with two guns of artillery) assigned to this force of picked men. This simply does not match what is known about Knox's plan for artillery deployment. Despite the fact that Scott's force numbered

\footnotetext{
35 “Court-Martial," 132-133.

${ }^{36}$ Ibid., 140.
} 
around 1400 men, the unit was of solid brigade strength and rightly should have been assigned only one artillery company, of two guns.

The first piece of evidence in the search for Scott's field gun number goes back to the "Scott and Wayne Memorandum." As was previously stated, this is the earliest extant primary source on the morning-phase artillery. The "Memorandum" clearly states ten guns with the advance corps. Missing from their description, interestingly, is Brigadier General Maxwell's New Jersey Brigade, with its two-gun artillery company. ${ }^{37}$ Further research indicates, however, that this listing may have incorporated Maxwell's forces in with Scott's own detachment, bringing the total artillery pieces to the correct proposed number of ten. This is suggested in the recollections of Colonel Marinus Willett, a volunteer aide serving on the staff of Brigadier General Scott. According to the Colonel's personal manuscript, Willett joined Scott's Detachment on June $23^{\text {rd }}$. Scott's force of "light infantry" was joined the next evening by the New Jersey Brigade under Maxwell. The following evening, June $25^{\text {th }}$, Scott and Maxwell's forces were joined by Brigadier General Wayne and his detachment. ${ }^{38}$ It is unclear why the gun counts presented by the "Memorandum" and Wayne's testimony do not match, however, all other accounts indicate the actual number being ten field pieces.

Colonel Willett provides additional evidence concerning the artillery found in Scott's Detachment. Willett served by General Scott's side throughout the entire morning portion of the battle. During the initial phase of the retreat, he noted that many of the field pieces of artillery had to break away from their parent brigades in order to avoid a marsh, which, based on the context of the narrative is likely the East Morass across the Spotswood Middlebrook. This was also the case

\footnotetext{
${ }^{37}$ Stryker, Battle of Monmouth, 284.

${ }^{38}$ William M. Willett, ed., A Narrative of the Military Actions of Colonel Marinus Willett, Taken Chiefly from His Own Manuscript (New York: G. \& C. \& H. Carvill, 1831), 66.
} 
with the guns assigned to Scott's Detachment, which Colonel Willet noted, very clearly and concisely, as having "charge of two field-pieces." 39

The last and perhaps best evidence comes from Lieutenant Colonel Oswald himself. In his testimony during the "Lee Court-Martial," Oswald denotes only ten guns in service with Lee's advance corps. Oswald states:

I brought out my two pieces into the plain...I ordered Captain Wells to limber up the pieces...I then formed the pieces that were with General Varnum's Brigade, the two pieces that I brought over, and the two pieces under Captain Seward in an orchard, and began to cannonade a column of the enemy that was advancing on our right...I discovered on my left General Maxwell's brigade and General Scott's detachment coming out of the wood upon this eminence I had formed for action, and had taken two pieces from General Scott's detachment and two from General Maxwell's brigade, making in all ten. ${ }^{40}$

This statement was further questioned by General Lee, asking:

Are you certain that it was General Scott's detachment and General Maxwell's brigade that you saw come out of the wood, or their artillery only?

A[nswer]. I am not certain that it was General Scott's detachment, but I got their artillery, and there was a body of men with the two pieces; but I am certain it was General Maxwell's brigade. ${ }^{41}$ [authors' emphasis]

General Scott's own testimony in the "Court-Martial" corroborates both Oswald's and Willett's statements:

I thought proper to repass a morass and take place in a wood with a morass in my front. About this time I sent my artillery immediately back the road I came, into the field, finding it impossible for them to act on the ground I had taken, or even to get to it. ${ }^{42}$

\section{Identifying the Companies}

\footnotetext{
${ }^{39}$ Willett, Narrative of the Military Actions of Colonel Marinus Willett, 68.

40 “Court-Martial," 134-135.

${ }^{41}$ Ibid., 137.

42 Ibid., 28.
} 
Having established the ten-gun solution to the initial inquiry, a final question remains: which artillery companies were they? The best way to determine this is to go back to the primary sources.

\begin{tabular}{|c|c|c|c|}
\hline \multicolumn{2}{|c|}{ ARTILLEY ASSIGNMENTS WITH THE CONTINENTAL ADVANCE CORPS } \\
BATTLE OF MONMOUTH, JUNE 28, 1778
\end{tabular}

\section{Preliminary Artillery Assignments, with Citations}

As was previously mentioned, Lieutenant Colonel Oswald observed the majority of the initial phases of the morning battle with Captain Thomas Wells' Artillery Company. Oswald indicates in his testimony in the "Lee Court-Martial" that Wells' Company was assigned to Scott's Brigade. Some historians have referred to this brigade as "Grayson's Detachment," a reference to the unit's commander during the Monmouth campaign, Colonel William Grayson. This has been done in an effort to distinguish Scott's Brigade, commanded by Grayson, from Scott's Detachment, which was commanded by Brigadier General Charles Scott. ${ }^{43}$

43 “Court-Martial," 130-133. 
The "Lee Court-Martial" also offers the infantry brigade assignments for two more artillery companies present with the advance corps. In the testimony of Lieutenant Colonel Jeremiah Olney, the officer indicates that Captain David Cook's Artillery Company was assigned to his brigade. Olney served as the commander of Varnum's Brigade following the serious wounding of the unit's

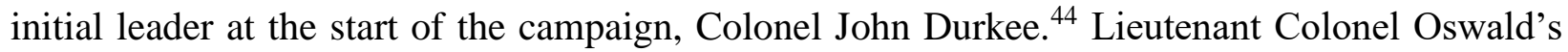
testimony also indicates the artillery company assigned to General Wayne's Detachment. Having stated that he was already with Wells' Company and had picked up the company connected to Varnum's Brigade (Cook) during the initial retreat, he then notes that he gathered under his fold Captain Thomas Seward's Artillery Company. As he later mentions that this picking up of Seward's Company was before getting the guns from Scott's Detachment and Maxwell's New Jersey Brigade, it can be deduced that Seward's Artillery Company was assigned to Wayne's Detachment. $^{45}$

The fourth company that can be identified was the one assigned to Brigadier General William Maxwell's New Jersey Brigade. The major source resolving this assignment comes not from the "Lee Court-Martial" but rather from the pension application file of Joseph Lummis. Major Joseph Bloomfield of the $3^{\text {rd }}$ New Jersey Infantry Regiment, New Jersey Brigade, indicates in his deposition for the Lummis application that, "in 1776 two Companies of Artillery were raised in New Jersey...the Company in West Jersey [was] arranged as one of the Companys of Lambs Artillery \& in 1778 Attached to the Jersey Brigade with two field Pieces."46 Joseph Lummis, who served as a drummer with the West Jersey Artillery Company in 1778, states in his own deposition

\footnotetext{
44 “Court-Martial," 127.

${ }^{45}$ Ibid., 134-135.

46 "Joseph Lummis Pension Application," 1818, in Index of Revolutionary War Pension Applications in the National Archives (Washington, DC: National Archives, 1976), microfilm, pension S41784, National Archives Microfilm Publication M804, reel 1601.
} 
that the unit was commanded by Captain Thomas Randall and "took winter quarters in Valley forge and in the Spring of 1778 was detached to the Jersey troops under the Command of General Maxfield [Maxwell] served in the Jersey line the Campaign of 1778." ${ }^{\circ 7}$ Based on these two solid references, it can be determined that Captain Randall's West Jersey Artillery Company was the unit assigned to General Maxwell's New Jersey Brigade. It should also be noted, tangentially, that this particular determination is not novel. It first appeared in the appendices of the well-researched and thoroughly-cited “'A Very Smart Cannonading Ensued from Both Sides:' Maxwell’s Jersey Brigade Artillery and the Afternoon Cannonade at Monmouth," authored by John U. Rees in $2003 .^{48}$

The fifth and final artillery company of the Continental advance corps is unknown. What is known is that this two-gun company would have been the artillery assigned to General Scott's Detachment of "picked men." Leaving this fifth company unknown is counter to the original purpose of this paper, which is to determine not only the number of guns in the morning but also to identify those field pieces. It is appropriate, therefore, to take a general survey of all the remaining artillery companies within the Continental Army to rule out the clear majority of them and to present several possible contenders.

\section{The Fifth Company?}

In examining the company muster rolls of the artillery regiments in the Continental Army during this period, certain determinations can be made. Each artillery company's monthly muster roll was signed by the commanding officer of the brigade to which they were assigned. Based on these findings, in addition to other circumstantial evidence found in primary sources, further

\footnotetext{
47 “Joseph Lummis Pension Application,” Revolutionary War Pension Applications, S41784.

48 John U. Rees, “Appendix J - 'A Very Smart Cannonading Ensued from Both Sides:' Maxwell's Jersey Brigade Artillery and the Afternoon Cannonade at Monmouth," Rev War '75 Research Library, 2003, http://revwar75.com/library/rees/monmouth/MonmouthJ.htm (accessed July 30, 2017).
} 
deductions can be made for the majority of the artillery companies concerning their assignments to the infantry brigades or the Artillery Park of Washington's army.

There are, however, four distinct artillery companies that stand out as being options for the company assigned to Scott's Detachment, due in large part to unclear assignment information and other known facts about these units. There is abundant evidence that each of these four companies saw combat during the battle. Going through this evidence, it becomes clear that one company stands out as most likely to have been attached to the advance corps in the morning at Monmouth, while the other three appear to have been active in the afternoon portion of the battle.

One of these units is Captain Sebastian Bauman's Artillery Company, an element of Colonel John Lamb's Artillery Regiment. As noted in the Memoir of the Life and Times of General John Lamb: An Officer of the Revolution, authored by Isaac Q. Leake and heavily reliant on the Lamb Papers found at the New-York Historical Society, Colonel Lamb was pleased to hear of the praise given to a number of his regiment's companies, including Bauman's, that were involved both at the Battle of Monmouth and in other army operations in mid-1778. ${ }^{49}$ According to Captain Bauman's June 1778 muster roll, which spanned June $3^{\text {rd }}$ to July $22^{\text {nd }}$, the unit did not suffer any casualties associated with combat. At this time, the company also appears to be under the command of Captain-Lieutenant Jacob Reed as the record states that Captain Bauman was on furlough and that Captain-Lieutenant George Fleming was on command with General DuPortail of the Continental Army's engineers. Interestingly, the company's officers are also listed as serving on quartermaster duty for the Artillery Brigade. ${ }^{50}$

\footnotetext{
${ }^{49}$ Isaac Q. Leake, Memoir of the Life and Times of General John Lamb: An Officer of the Revolution, 1857, American Revolutionary War Series (reprint, Bedford, MA: Applewood Books, 2009), 202.

50 "Muster Roll of Capt. Sebastian Bauman's Company for the Month of June 1778," 1778, in Revolutionary War Rolls, 1775 - 1783 (Washington, DC: National Archives, 1894-1913), microfilm, NARA M246, record group 93, roll 0118 , Fold3.
} 
The other important item to note on the June muster roll for Bauman's Company is the officer who signed off on the roll. According to the entry, Colonel Philip Cortlandt (some historical sources give his name as Van Cortlandt), commanding officer of the $2^{\text {nd }}$ New York Regiment and commandant of Poor's Brigade, signed the muster roll for the company. At the Battle of Monmouth, Colonel Cortlandt led Poor's Brigade as part of Lord Stirling's left wing during the afternoon portions of the fighting. Despite almost a month's period of time between the Battle and the signing of the roll on July $22^{\text {nd }}$, it is unlikely that Bauman's Company would have been reassigned to another unit following the Battle. That intervening month saw the Army on the march, jockeying into positions scattered across northern New Jersey, the lower Hudson Valley of New York, and into Connecticut in an effort to pen up British forces concentrating their strength in New York following the Monmouth campaign. Based on these observations, it is most plausible that Bauman's Company was assigned to Poor's Brigade, disqualifying the unit as a contender for the assignment with Scott's Detachment in the morning of the Battle of Monmouth. Additional evidence supports this as other artillery units' muster rolls were also signed by Colonel Cortlandt, namely Captain John Doughty's Artillery Company and Captain Samuel Mansfield's Artillery Company, denoting these units as most likely serving with Stirling's brigades in the afternoon at Monmouth. ${ }^{51}$ These conclusions strongly merit further investigation as to the role of these companies in the battle.

Two other units are from Colonel John Crane’s Artillery Regiment - Captain Benjamin Eustis' Company and Captain William Perkins' Company. These two units share a unique

\footnotetext{
51 “Muster Roll of Capt. Bauman's Company June 1778;" Lender \& Stone, Fatal Sunday, 457-458; "Muster Roll of Capt. John Doughty's Company for the Month of June 1778," 1778, in Revolutionary War Rolls, 1775 - 1783 (Washington, DC: National Archives, 1894-1913), microfilm, NARA M246, record group 93, roll 0118, Fold3; "Muster Roll of Capt. Samuel Mansfield's Company for the Month of June 1778," 1778, in Revolutionary War Rolls, 1775 - 1783 (Washington, DC: National Archives, 1894-1913), microfilm, NARA M246, record group 93, roll 0119, Fold3.
} 
distinction in that of all the artillery companies in Washington's army with unclear assignments, these two groups do not have existing muster rolls for June 1778. In the month prior, both companies had their muster rolls signed by Brigadier General Henry Knox, indicating that they both served as part of the Artillery Park prior to departing from Valley Forge. Of the two units, only Eustis' Company has a muster roll right after Monmouth, with Lieutenant Colonel Samuel Smith of the $4^{\text {th }}$ Maryland Regiment, $2^{\text {nd }}$ Maryland Brigade, signing off on this entry for July of $1778 .{ }^{52}$ Due to the similarities between the two companies in missing muster rolls for June of 1778 and assignments to the Artillery Park in the month prior, yet with one of the companies having an assignment with an infantry brigade in July, it is not likely that either unit served with General Scott's Detachment at Monmouth; rather, the more likely scenario is that these units served together elsewhere, either in the Artillery Park or at some other yet-to-be-determined position on the battlefield.

The most likely candidate is Captain Andrew Porter's Artillery Company. Another element of Colonel Lamb's Regiment, this unit had its June 1778 muster roll signed on July $10^{\text {th }}$ by Lieutenant Colonel William Butler, commanding officer of the $4^{\text {th }}$ Pennsylvania Regiment and acting commander of the $2^{\text {nd }}$ Pennsylvania Brigade. At Monmouth, Butler was pulled from his standing unit to command a battalion of picked men assigned to Scott's Detachment in Lee's advance corps. ${ }^{53}$ That month's muster roll indicates that the company was possibly commanded by the unit's captain-lieutenant, James McClure, during its time at Monmouth as the record

\footnotetext{
52 "Muster Roll of Capt. Benjamin Eustis' Company for the Month of July 1778," 1778, in Revolutionary War Rolls, 1775 - 1783 (Washington, DC: National Archives, 1894-1913), microfilm, NARA M246, record group 93, roll 0120, Fold3.

53“"Muster Roll of Capt. Andrew Porter's Company for the Month of June 1778," 1778, in Revolutionary War Rolls, 1775 - 1783 (Washington, DC: National Archives, 1894-1913), microfilm, NARA M246, record group 93, roll 0120, Fold3; John U. Rees, "Appendix C - 'General Lee being detached with the advanced Corps...' Composition of Charles Lee's Division,” RevWar '75 Research Library, 2003, http://revwar75.com/library/rees/monmouth/MonmouthC.htm (accessed September 30, 2018).
} 
indicates that Captain Porter himself was "absent with leave" at some point during the period of June $1^{\text {st }}$ to July $10^{\text {th }}$. More importantly, however, are the casualties incurred during the Battle of Monmouth as depicted in the muster roll, stating that on June $28^{\text {th }}$, Second Lieutenant Ezekiel Howell was wounded, and that First Lieutenant James McNair was killed. ${ }^{54}$ The loss of Lieutenant McNair is the more telling piece of evidence of these two casualties as William S. Stryker, in his The Battle of Monmouth, depicts his death as resulting from decapitation from artillery fire by the British during the morning portion of the Battle of Monmouth. ${ }^{55}$

Based on the review of these facts, it becomes clear that Captain Porter's Company stands out as the leading candidate for the two-gun artillery unit assigned to Scott's Detachment. The company's June muster roll was signed by William Butler, a subordinate commander in Scott's Detachment, on July 10, 1778, less than two weeks after the fighting at Monmouth on June $28^{\text {th }}$. Additionally, Stryker notes the death of Lieutenant McNair in the morning phase of the battle. Despite not knowing the source that the author used in making this assertion, and taking into account the "alterations and subtractions" made by Stryker's editor as was previously mentioned, this placing of McNair's death in this period serves as strong secondary evidence supporting this assertion that McNair's unit, Captain Porter's Company, served in Lee's advance corps and would have been the final unnamed company attached to Scott's Detachment.

\section{Conclusion}

In conclusion, confused secondary sources on the subject have muddied the matter of "tenor-twelve guns" in the morning at Monmouth by repeatedly using one divergent primary reference, a situation that has perpetuated to the present day. Historians over the years have concentrated their primary source research solely on a single document. They have centered their discussion on

\footnotetext{
54 "Muster Roll of Capt. Porter's Company, June 1778."

${ }^{55}$ Stryker, The Battle of Monmouth, 200.
} 
the evidence as presented in the testimony found in the "Lee Court-Martial," often to the exclusion of other primary documents. The analysis presented in this paper, however, strives to incorporate all of the primary sources within the discussion of the morning artillery and its number of guns.

In going back and reanalyzing the primary sources, several competent documents stand out, including the "Memorandum" by Generals Scott and Wayne, indicating that there were ten pieces of artillery with Lee's advance corps. Lieutenant Colonel Oswald, the morning's senior artillery advisor, indicates in his testimony in the "Lee Court-Martial" that as the situation deteriorated during the retreat he began picking up artillery companies from the brigades to form a "grand battery" to delay the pursuing British and buy time for Continental forces to fall back towards Washington's lines. Oswald states that he collected ten guns, a figure which represents the total number present with the advance corps and which perfectly corresponds to the "one infantry brigade, one two-gun artillery company" system utilized by General Knox during this period.

Included in the ten guns Oswald collected was the two-gun artillery company from Scott's Detachment, not four guns (two companies) as is often described in most secondary sources. Colonel Willett, whose memoirs are a seldom-used primary source in the historiography, clearly and firmly states two guns as being with Scott's Detachment. Period muster rolls and other interpreted evidence suggest Captain Andrew Porter's Artillery Company as the candidate for this unit's identity. The remainder of Oswald's testimony and other strong primary sources are clear as to the remaining four artillery companies, their number of guns, and their parent brigades. 


\begin{tabular}{|c|c|c|}
\hline \multicolumn{2}{|c|}{ ARTILLEY ASSIGNMENTS WITH THE CONTINENTAL ADVANCE CORPS } \\
BATTLE OF MONMOUTH, JUNE 28, 1778 \\
\hline INFANTRY BRIGADE OR DETACHMENT & ARTILLERY COMPANY ASSIGNED & NUMBER OF GUNS \\
\hline Scott's Brigade (also known as Grayson's Detachment) & Captain Thomas Wells' Artillery Company & $\mathbf{2}$ guns \\
\hline Varnum's Brigade (also known as Durkee's Detachment) & Captain David Cook's Artillery Company & $\mathbf{2}$ guns \\
\hline Wayne's Detachment & Captain Thomas Seward's Artillery Company & $\mathbf{2}$ guns \\
\hline Scott's Detachment & \{Captain Andrew Porter's Artillery Company & $\mathbf{2}$ guns \\
\hline Maxwell's New Jersey Brigade & Captain Thomas Randall's Artillery Company & $\mathbf{2}$ guns \\
\hline
\end{tabular}

Final Artillery Assignments

In the end, the evidence presented clearly indicates that there were ten pieces of artillery (five companies) with Lee's advance corps during the morning phase of the Battle of Monmouth on June 28, 1778. By going back to the original documents and sources, and not taking the secondary sources for granted, this paper presents a solution to this particular inquiry. The model presented here represents a total reevaluation and new interpretation of all the evidence available, guided by the use of primary sources. Future interpretations of other aspects of the battle may benefit from the usage of this model. The implications of these conclusions allow for further speculation, including hypothetical discourse on the impact that the number of artillery pieces would have had on the course of the morning's battle.

Michael Timpanaro is currently the Resource Interpretive Specialist at Monmouth Battlefield State Park in Manalapan, New Jersey, serving as the Park Historian. He has over thirty-five years' experience as an archaeologist, historic researcher, and historian. He has worked on archeological sites in North America dating from the earliest inhabitants through the twentieth century, and in Europe on Neolithic, Bronze Age and Roman sites. 
Victor Pidermann (M.A. History, Monmouth University, 2014) is a Senior Seasonal Educational Interpreter of History at Monmouth Battlefield State Park and has also served in the past as an Adjunct Professor of History at Monmouth University. 